\title{
Are Male and Female Students Different in High-Order Thinking Skills?
}

\author{
Dewi Endah Sari', lin Hindun², Nurul Mahmudati², \\ Fuad Jaya Miharja ${ }^{2}$, Ahmad Fauzi ${ }^{2}$ \\ 1 State Senior High School 1 of Malang, Malang, East Java, Indonesia \\ 2 Biology Education Department, University of Muhammadiyah Malang, Malang, East Java, Indonesia \\ e-mail: dewiarismansa@yahoo.co.id, iinhindunhindun@yahoo.co.id,nurul.mahmudati@yahoo.com, \\ fuad.jayamiharja@umm.ac.id, ahmad_fauzi@umm.ac.id
}

\begin{abstract}
High-order thinking skills (HOTS) are competencies that must be possessed by male and female students in $21^{\text {st }}$ Century era. The purpose of this quasi-experimental pretest-posttest design was to determine the effect of gender on the level of HOTS empowerment of high school students. The subjects of this study were students of SMA Negeri 1 Malang and the sample of the study was students of class XI MIPA 10. All students receive biology learning by applying Problem-based Learning (PBL) combined with Two Stay-Two Stray (TSTS) assisted by "Sangkar Hati" media. The collected data were analyzed by using one-way ANCOVA. Based on the results of data analysis, it can be concluded that HOTS achievement of female students is not significantly different from male students. Through the findings of this study, it is expected that the implementation of Biology learning in other schools will also implement innovative education with creative media that can empower HOTS of female and male students.
\end{abstract}

Keywords: High-Order Thinking; Innovative; Media; Gender

\section{Introduction}

In the current era, many educators in various parts of the world are busy considering how to prepare the best way for young people to face an ever-changing world (Yeung, 2015). An ever-changing world requires students to be able to think critically and analytically in various unexpected situations (Belecina \& Ocampo, 2018; Donald, 2012). The students also must be ready to implement the basic knowledge that they have when facing various unpredictable problems. Preparing students for various challenges after they will not work optimally if the learning process focuses only on mastering low cognitive level (Kusuma, Rosidin, Abdurrahman, \& Suyatna, 2017; Mainali, 2012). Therefore, empowerment of highorder thinking skills (HOTS) is one of the main goals of education in this $21^{\text {st }}$ Century era (Chinedu \& Olabiyi, 2015; Jerome, Lee, \& Ting, 2017).

Empowerment of thinking skills can be done through training and habituation. Training and habituation can be packaged into various learning designs that are believed to be able to empower students' thinking skills (Fauzi, 2013; Sada, Mohd, Adnan, \& Yusri, 2016; Thompson, 2017). In addition, the integration and modification of various learning models also have been carried out by researchers to further optimize the $21^{\text {st }}$ Century competencies (Asyari, Muhdhar, Susilo, \& Ibrahim, 2016). Based on many published research reports, apart from various concepts that are difficult for students to learn (Etobro \& Fabinu, 2017; Fauzi \& Fariantika, 2018; Fauzi \& Mitalistiani, 2018), Biology is known as one of the most potentially increasing subjects for student's thinking skills (Donald, 2012).

In addition to choose the right learning model, the use of learning media is an essential component in improving the quality of learning (Naz \& Akbar, 2010). The use of learning media can optimize the delivery of messages during the learning process and increase students' motivation (Rajendra \& Sudana, 2018; Widiansyah, Indriwati, Munzil, \& Fauzi, 2018). Besides, the existence of learning media can increase students' attachment to the

\footnotetext{
"Corresponding author.

Received 22 May 2019; Accepted 14 March 2020; Available online 31 March 2020 (c) 2020 JPI. All Rights Reserved
} 
learning activities. When the level of student engagement is high, learning objectives will be easier to be achieved (Arulmoly \& Branavan, 2017; Logan, Lundberg, Roth, \& Walsh, 2017; Valerio, 2012), including learning goals that related to students' high-order thinking skills.

In designing HOTS-based learning, educators must also pay attention to the gender issues and their influence on the learning process. Gender is a demographic factor that often attracts attention to be studied in the world of education (Voyer \& Voyer Susan D., 2014). On one hand, some studies report gender does not have a significant effect on students' academic achievement (Faisal, Shinwari, \& Hussain, 2017; Prianto et al., 2018). On the other hand, others report the opposite. When gender is reported having a significant influence, the diversity of findings is also concluded. Some studies found that female students can achieve higher levels of academic success than male students (Sari et al., 2018; Zainal, Yahya, \& Abdul Rahman, 2014), there are also studies that have the contradictory findings (Musa, Dauda, \& Umar, 2016). If gender is able to provide a significant influence on the empowerment level of thinking skills, educators need to design the learning activities that can empower female and male students' HOTS.

Unfortunately, educator's understanding and awareness of the importance of HOTS empowerment in Indonesia is still uneven (Ramdiah, Abidinsyah, Royani, \& Husamah, 2019). In addition, knowledge about the application of HOTS-based learning is also still in the low category (Retnawati, Djidu, Kartianom, Apino, \& Anazifa, 2018). However, there are many existing educational institutions that consistently implement innovative HOTS-based learning. One of these educational institutions is SMAN 1 Malang.

Based on the observation results of learning activities and interviews with teachers at SMAN 1 Malang, Problem-based Learning has been consistently applied in Biology learning at the school. Problem-based Learning (PBL) is one of the learning models that is recommended to be applied in various science subjects (Afni, Zahroh, Anwar, Irjasy, \& Fauzi, 2018; Argaw, Haile, Ayalew, \& Kuma, 2017; Hamoush, Fini, Parast, \& Sarin, 2011; Yusof, Hassan, Jamaludin, \& Harun, 2012). The reason is because various studies report the positive impact of PBL on various parameters of education, including empowering students' thinking skills (Jonassen, 2011; Nazir \& Zabit, 2010; Talat \& Chaudhry, 2014).

In addition to be consistent in implementing PBL, the Biology teachers at SMAN 1 Malang are also accustomed to actively innovate, modify, and integrate PBL with other forms of learning. One modification that has been done is by combining PBL with two stay-two stray (TSTS). Besides, learning innovations are also carried out on the application of various creative learning media. One of the innovative medias that is developed by Biology teachers is "Sangkar Hati" media (the media which is from the abbreviation of pasang dan bongkar jaringan hewan dan tumbuhan tingkat tinggi / putting the unloading tissue of high animal and plant). This learning media is used by the teachers in Biology learning to discuss the material tissue of living things.

However, research that studies about the implementation of innovative learning in SMAN 1 Malang has never been done before. Therefore, the study of the effect of gender on empowerment of students' HOTS after participating in Problem-based Learning (PBL) combined with two stay-two stray (TSTS) assisted by "Sangkar Hati" media needs to be conducted. Then, the results of this study can give information whether there is a different level of HOTS empowerment between female and male students or not when they followed innovative learning in Biology class.

\section{Method}

This study was a quasi-experimental pretest-posttest study that was conducted on June to July 2018. The population of the study was eleventh grade students of SMAN 1 Malang, Indonesia. The sample was students of class XI MIPA 10. In this study, gender was a variable and HOTS empowerment was the dependent variable. The study was conducted on the "plant tissue" material which was held for four meetings.

Before the first meeting, the students took a part in the pre-test activity. In the next meeting, students took a part in learning that applied the PBL learning model combined with TSTS assisted by "Sangkar Hati" media. The stages of learning were designed as follows. 
(1) Each group received an envelope containing images that represent biological phenomena that must be solved. One group consisted of four to five students. Biological phenomena were positioned as problems. The problems between the groups were different. (2) Each group prepared six questions related to the problems they received. The questions referred to ABDIKASIM or $5 \mathrm{~W}+1 \mathrm{H}$ questions (apa/what, bagaimana/how, dimana/where, kapan/when, siapa/who, and mengapa/why). These questions were written on laminated paper in the clouds shape. (3) Each group wrote the answers of the questions they made after they conducted a literature study. The answer was written in the pieces with laminated leaves. (4) The clouds containing questions and leaves containing answers were affixed and arranged as creative as possible on the poster with a tree size X-banner. The leaves, clouds and posters are named as "Sangkar Hati" media. (5) Each group exhibited their work. At this stage, two students remained in their group to present their work, while two students shopped for information from another group. After the fourth meeting, students took a part in the post-test activity.

The pre-test and post-test instruments consisted of high-level thinking questions (C3 and C4 cognitive levels). The pretest instrument consisted of 35 questions that asked about membrane transport material, while the posttest instrument consisted of 28 questions about plant tissue material. These questions were the items that were categorized as valid. The obtained data from pretest and posttest scores were analyzed through one-way analysis of covariance (ANCOVA). Before the hypothesis test was carried out, the data were tested for the homogeneity using the Kolmogorov-Smirnov test and its homogeneity using the Levene test. When the data met the assumptions of normality and homogeneity, the data were continued to be analyzed by using ANCOVA. Assisted data analysis of SPSS 22.0 with $\alpha=$ 0.05 .

\section{Result and Discussion}

HOTS is an essential competency in the current era. Some research reports indicate that gender can influence the empowerment level of HOTS. In this study, the influence of demographic factors was assessed through students' ability to answer HOTS questions. HOTS score data of female and male students is presented in Figure 1. Based on Figure 1, there are differences in mean scores between female and male students. At the pretest activity, male students had a higher average score, but the opposite occurred in the posttest data. Furthermore, because the data met the assumptions of normality ( $p$-value $=0.122$ ) and homogeneity ( $p$-value $=0.874$ ), then the data were analyzed by using ANCOVA. A summary of the results of the hypothesis test is presented in Table 1.

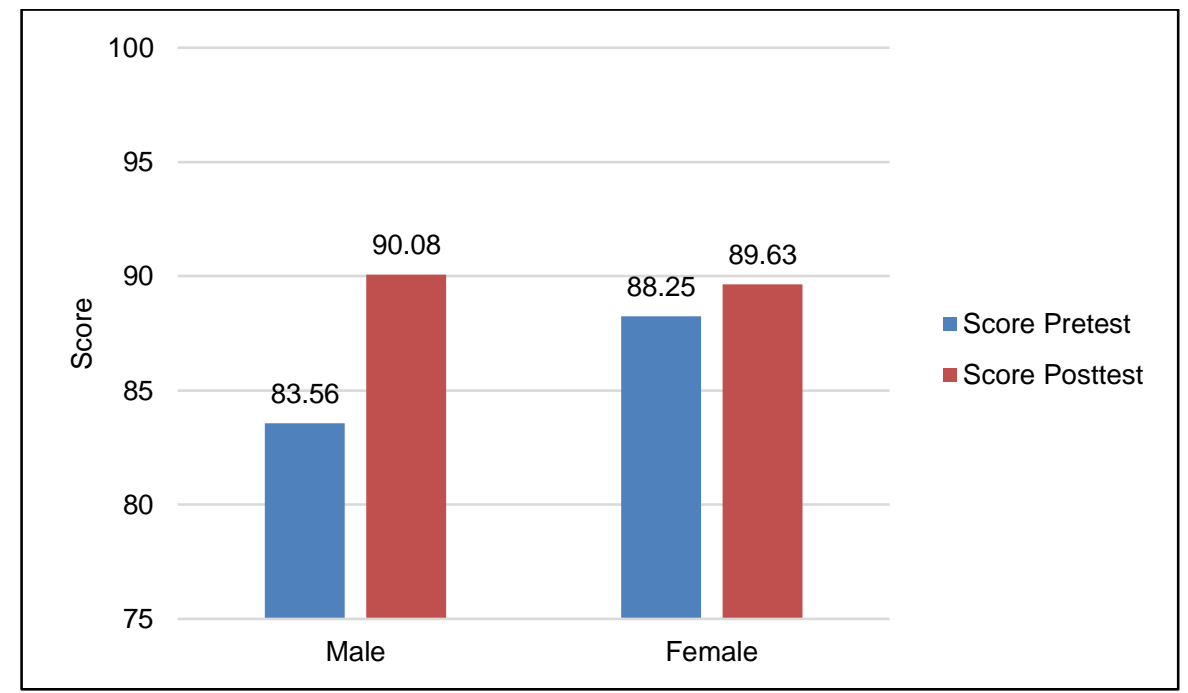

Figure 1. The average of students' pre-test and post-test scores in Biology learning by using PBL combined with TSTS assisted by "Sangkar Hati" media. 
Table 1. Summary of ANCOVA test results on gender influence on HOTS students

\begin{tabular}{cccc}
\hline Source & df & F & Sig. \\
\hline Pretest & 1 & .468 & .503 \\
Gender & 1 & .093 & .763 \\
Error & 18 & & \\
\hline
\end{tabular}

In addition, Table 1 shows that the $F$ calculated gender factor is 0.093 with $p$-value of 0.763 ( $p$-value> $\alpha)$. Thus, the results of the data analysis show that the HOTS achievement of female students is not significantly different from male students. This finding indicates that the application of innovative learning assisted by creative media at SMAN 1 Malang empowers female and male students' HOTS at a level that is not significantly different. This finding is in line with several previous studies which found that gender differences did not have a significant effect on students' academic achievement.

Gender is indicated to be able to influence the achievement level of students' HOTS. In addition, some studies about the influence of gender on students' academic achievment also informed that gender can influence the students' learning motivation level(King, 2016) to preferences of learning topics that favored by students (Lindberg, Hyde, Petersen, \& Linn, 2011). However, with the right choice of learning design, empowering male students competencies will be as good as female students.

In this study, PBL combined with TSTS was used as the learning design. In each learning material, students were encouraged to solve various problems related to the material. Habiting students to deal with various problems will facilitate them to get used to analyze the situation at hand (Jonassen, 2011; Roberto \& Ribeiro, 2011; Sada et al., 2016). The habit of arranging and answering high-level questions will also familiarize students with their HOTS (Chinedu \& Olabiyi, 2015). When they answer the specific questions, students can also be encouraged to apply the knowledge that they understand to answer the problems.

The application of "Sangkar Hati" media also played a role in students' HOTS achievement. The reason is the existence of exciting learning media will increase student learning motivation (Rajendra \& Sudana, 2018; Widiansyah et al., 2018). In addition, learning media are also able to increase students' attachment to the learning activities. Both of these are reflected in the cheerful attitude and enthusiasm of the students when participating in the learning activities that involved the media. The high motivation to learn and the attachment to the learning process will further optimize the achievement of learning goals that have been designed by the teacher (Abbing, 2013; Arulmoly \& Branavan, 2017; Valerio, 2012), including learning goals related to the increasing of students' HOTS.

The integration of TSTS in the learning process could facilitate each group to learn various biological phenomena even though the phenomenon does not become a problem that they received in their own group. This condition can overcome the limitations of learning time allocation which requires students to master different knowledge in a limited time. Mastery of knowledge is related to the students' ablity in understanding the learning material. Understanding is a low-level of cognitive level. However, low-level cognitive mastery is one of the optimal keys to high-level cognitive mastery. In addition, TSTS is also reported to be able to improve student self-efficacy (Kurnia, Degeng, \& Soetjipto, 2017). Self-efficacy is one of the determinants of optimizing competency empowerment during the learning (Köseoğlu, 2015). The reason is besides being positively correlated with learning motivation (Hassankhani, Mohajjel Aghdam, Rahmani, \& Mohammadpoorfard, 2015), self-efficacy can increase students' perseverance in their learning and endurance when participating in learning activities (Phan \& Ngu, 2014).

\section{Conclusion}

In this study, it can be seen that the HOTS achievement of female and male students is not significantly different. Thus, it is indicated that the application of innovative learning assisted by "Sangkar Hati" media can empower HOTS of female and male students at the 
same level. Through the result of this study, it is expected that educators in other schools will also organize and design an innovative learning that can empower students' HOTS.

\section{Acknowledgement}

This study was carried out with the collaboration and support of the Ministry of Research, Technology and Higher Education through a funding scheme for Assigning Lecturers in Schools/Penugasan Dosen di Sekolah (PDS), Dean of Faculty of Teacher Training and Education (FTTE), and Headmaster of SMAN 1 Malang. .

\section{References}

Abbing, J. (2013). The effect of students' engagement on academic achievement in different stages of Their academic career from a dropout perspective.

Afni, M., Zahroh, A., Anwar, N., Irjasy, A., \& Fauzi, A. (2018). Pembiasaan penerapan model problem based learning dan dampaknya terhadap peningkatan penguasaan konsep biologi siswa SMA. In Prosiding Seminar Nasional IV 2018: Peran Biologi dan Pendidikan Biologi dalam Revolusi Industri 4.0 dan Mendukung Pencapaian Sustainability Development Goals (SDG's) (pp. 23-30).

Argaw, A. S., Haile, B. B., Ayalew, B. T., \& Kuma, S. G. (2017). The effect of problem based learning (PBL) instruction on students' motivation and problem solving skills of physics. Eurasia Journal of Mathematics, Science and Technology Education, 13(3), 857-871. https://doi.org/10.12973/eurasia.2017.00647a.

Arulmoly, C., \& Branavan, A. (2017). The impact of motivation on student's academic achievement and learning outcomes in mathematics among secondary school students in Nigeria. International Journal of Scientific and Research Publications, 7(5), 115-126.

Asyari, M., Muhdhar, M. H. I. Al, Susilo, H., \& Ibrahim. (2016). Improving critical thinking skills thorugh the intergration of problem based learning and grup investigation. International Journal for Lesson and Learning Studies, 5(1), 36-44.

Belecina, R. R., \& Ocampo, J. M. (2018). Effecting change on students' critical thinking in problem solving. EDUCARE: International Journal for Educational Studies International Journal for Educational Studies Article Timeline: Accepted, 10(102), 109-118.

Chinedu, C. C., \& Olabiyi, O. S. (2015). Strategies for improving higher order thinking skills in teaching and learning of design and technology education. Journal of Technical Education and Training, 7(2), 35-43. https://doi.org/10.1109/TMI.2011.2171706.

Donald, G. M. (2012). Teaching critical \& analytical thinking in high school biology? The American Biology Teacher, 74(3), 178-181. https://doi.org/10.1525/abt.2012.74.3.9.

Etobro, A. B., \& Fabinu, O. E. (2017). Students' perceptions of difficult concepts in Biology in senior secondary schools in Lagos State. Global Journal of Educational Research, 16, 139-147.

Faisal, R., Shinwari, L., \& Hussain, S. S. (2017). Academic performance of male in comparison with female undergraduate medical students in pharmacology examinations. Journal of the Pakistan Medical Association, 67(2), 204-208.

Fauzi, A. (2013). Pengaruh kemampuan akademik terhadap keterampilan metakognitif, hasil belajar biologi, dan retensi siswa SMA Kelas $X$ dengan penerapan strategi pembelajaran cooperative script di Malang. Universitas Negeri Malang. https://doi.org/10.13140/RG.2.2.24659.99363

Fauzi, A., \& Fariantika, A. (2018). Courses perceived difficult by undergraduate students majoring in biology. Biosfer: Jurnal Pendidikan Biologi, 11(2), 78-89. https://doi.org/10.21009/biosferjpb.v11n2.78-89

Fauzi, A., \& Mitalistiani. (2018). High school biology topics that perceived difficult by undergraduate students. Didaktika Biologi: Jurnal Penelitian Pendidikan Biologi, 2(2), 73-84.

Hamoush, S., Fini, E. H., Parast, M. M., \& Sarin, S. (2011). The effect of project-based learning (PBL) on improving student learning outcomes in transportation engineering. In Society for Engineering Education. Vancouver: American Society for Engineering Education. 
Hassankhani, H., Mohajjel Aghdam, A., Rahmani, A., \& Mohammadpoorfard, Z. (2015). The relationship between learning motivation and self efficacy among nursing students. Research and Development in Medical Education, 4(1), 97-101. https://doi.org/10.15171/rdme.2015.016

Jerome, C., Lee, J. A.-C., \& Ting, S.-H. (2017). What students really need: instructional strategies that enhance higher order thinking skills ( hots) among unimas undergraduates. International Journal of Business and Society, 18(4), 661-668.

Jonassen, D. (2011). Supporting problem solving in PBL. Interdisciplinary Journal of Problem-Based Learning, 5(2), 95-119. https://doi.org/10.7771/1541-5015.1256

King, R. B. (2016). Gender differences in motivation, engagement and achievement are related to students' perceptions of peer-but not of parent or teacher-attitudes toward school. Learning and Individual Differences, 52, 60-71. https://doi.org/10.1016/j.lindif.2016.10.006

Köseoğlu, Y. (2015). Self-efficacy and academic achievement - A case from Turkey. Journal of Education and Practice, 6(29), 131-141. https://doi.org/ISSN 2222-288X

Kurnia, N., Degeng, I. N. S., \& Soetjipto, B. E. (2017). The implementation of find someone who and two stay two stray models to improve students' self-efficacy and social studies learning outcomes. IOSR Journal of Research \& Method in Education (IOSR-JRME), 7(3), 66-70. https://doi.org/10.9790/7388-0703016670

Kusuma, M. D., Rosidin, U., Abdurrahman, A., \& Suyatna, A. (2017). The development of higher order thinking skill (HOTS) instrument assessment In physics study. IOSR Journal of Research \& Method in Education (IOSRJRME), 7(1), 26-32. https://doi.org/10.9790/7388-0701052632

Lindberg, S. M., Hyde, J. S., Petersen, J. L., \& Linn, M. C. (2011). New trends in gender and mathematics performance: A meta-analysis. Psychol Bull, 136(6), 1123-1135. https://doi.org/10.1037/a0021276.New

Logan, J. W., Lundberg, O. H., Roth, L., \& Walsh, K. R. (2017). The effect of individual motivation and cognitive ability on student performance outcomes in a distance education environment. Journal of Learning in Higher Education, 13(1), 83. Retrieved from https://files.eric.ed.gov/fulltext/EJ1139727.pdf

Mainali, B. P. (2012). Higher order thinking in education. Academic Voices: $A$ Multidisciplinary Journal, 2(1), 5-10.

Musa, A. K. J., Dauda, B., \& Umar, M. A. (2016). Gender differences in achievement goals and performances in english language and mathematics of senior secondary schools students in Borno State , Nigeria. Journal of Education and Practices, 7(27), 165-175.

Naz, A. A., \& Akbar, R. A. (2010). Use of media for effective instruction its importance: Some consideration. Journal of Elementary Education, 18(1-2), 35-40. https://doi.org/10.20472/TE.2015.3.3.002

Nazir, M., \& Zabit, M. (2010). Problem-based learning on students' critical thinking skills in teaching business education in Malaysia: A literature review. American Journal of Business Education, 3(6), 19-32.

Phan, H. P., \& Ngu, B. H. (2014). Interrelations between self-esteem and personal selfefficacy in educational contexts: An empirical study. International Journal of Applied Psychology, 4(3), 108-120. https://doi.org/10.5923/j.ijap.20140403.05

Prianto, A., Qusthonthiniyah, A., Septiana, A., Tosiana, R., Ariani, N. N., Maulidyah, D. N., \& Fauzi, A. (2018). Capaian akademik mahasiswa ditinjau dari perbedaan gender. In Prosiding Seminar Nasional IV 2018: Peran Biologi dan Pendidikan Biologi dalam Revolusi Industri 4.0 dan Mendukung Pencapaian Sustainability Development Goals (SDG's) (pp. 62-67).

Rajendra, M. I., \& Sudana, M. I. (2018). The influence of interactive multimedia technology to enhance achievement students on practice skills in mechanical technology. In Journal of Physics: Conference Series (Vol. 953, pp. 0-5). IOP Publishing. https://doi.org/10.1088/1742-6596/953/1/012104

Ramdiah, S., Abidinsyah, Royani, M., \& Husamah. (2019). Understanding, planning, and implementation of HOTS by senior high school biology teachers in Banjarmasin- 
Indonesia. International Journal of Instruction, 12(1).

Retnawati, H., Djidu, H., Kartianom, K., Apino, E., \& Anazifa, R. D. (2018). Teachers' knowledge about higher-order thinking skills and its learning strategy. Problem of Education in the 21st Century, 76(2), 215-230.

Roberto, L., \& Ribeiro, C. (2011). The pros and cons of problem-based learning from the teacher's standpoint. Journal of University Teaching and Learning Practise, 8(1), 1-17.

Sada, A. M., Mohd, Z. A., Adnan, A., \& Yusri, K. (2016). Prospects of problem-based learning in building critical thinking skills among technical college students in Nigeria. Mediterranean Journal of Social Sciences, 7(3), 356-365. https://doi.org/10.5901/mjss.2016.v7n3p356

Sari, R. P., Maghfiroh, P. N., Suprapti, R., Firdausi, Z., Fajriani, N., \& Fauzi, A. (2018). Perbedaan indeks prestasi di berbagai program studi pendidikan ditinjau dari gender mahasiswa. In Prosiding Seminar Nasional IV 2018: Peran Biologi dan Pendidikan Biologi dalam Revolusi Industri 4.0 dan Mendukung Pencapaian Sustainability Development Goals (SDG's) (pp. 31-38).

Talat, A., \& Chaudhry, H. F. (2014). The effect of PBL and 21st century skills on students' creativity and competitiveness in private schools. The Lahore Journal of Business, 2(2), 89-114.

Thompson, T. (2017). Teaching creativity through inquiry science. Gifted Child Today, 40(1), 29-42. https://doi.org/10.1177/1076217516675863

Valerio, K. M. (2012). Intrinsic motivation in the classroom. Journal of Student Engagement: Education Matters, 2(1), 30-35.

Voyer, D., \& Voyer Susan D., D. (2014). Gender differences in scholastic achievement: A meta-analysis. Psychological Bulletin, 140(4), 1174-1204. https://doi.org/10.1037/a0036620

Widiansyah, A. T., Indriwati, S. E., Munzil, \& Fauzi, A. (2018). I-invertebrata as an androidbased learning media for molluscs, arthropods, and echinoderms identification and its influence on students' motivation. JPBI (Jurnal Pendidikan Biologi Indonesia), 4(1), 4352. https://doi.org/10.22219/jpbi.v4i1.5476

Yeung, S. yin S. (2015). Conception of teaching higher order thinking: Perspectives of Chinese teachers in Hong Kong. Curriculum Journal, 26(4), 553-578. https://doi.org/10.1080/09585176.2015.1053818

Yusof, K. M., Hassan, S. A. H. S., Jamaludin, M. Z., \& Harun, N. F. (2012). Cooperative Problem-based Learning (CPBL): Framework for Integrating Cooperative Learning and Problem-based Learning. Procedia - Social and Behavioral Sciences, 56(Ictlhe), 223232. https://doi.org/10.1016/j.sbspro.2012.09.649

Zainal, R., Yahya, R., \& Abdul Rahman, K. (2014). Influences of gender on academic achievement of Fiber Optic Communication System: An experience of Politeknik Merlimau Melaka. IOSR Journal Of Humanities And Social Science (IOSR-JHSS), 19(8), 108-111. 